\title{
Selecting a Strategic Logistics Service Provider for Subsea Engineering Companies on the Tweneboa, Enyenra and Ntomme (TEN) Project in Ghana
}

\author{
Emmanuel Sena Gohoho ${ }^{1}$, Jonas Aryee ${ }^{1}$ and George Kobina van Dyck ${ }^{1,2}$ \\ 1. Department of Ports and Shipping, Regional Maritime University, P. O Box GP 1115, Accra, Ghana \\ 2. School of Economics and Management, Shanghai Maritime University, Shanghai 201306, China
}

\begin{abstract}
The research dealt with assessment of logistics service providers' capabilities in SECs (supporting subsea engineering companies) on the Tweneboa, Enyenra and Ntomme (TEN) project in Ghana. SECs need logistics service providers who offer consolidated services for project optimization and fulfillment of local content requirements of the project. Relevant Staff of 7 SECs and 10 logistics service providers in Ghana formed part of the target group. The weighted scoring model was used in selecting a logistics service provider based on certain criteria. The selection criteria included Quality, Health, Safety and Environmental (QHSE) policies [Q], Compliance to regulations (GRA, Work permit, petroleum regulation) [C], Delivery of goods on time and response rate to deliver [D], Vessel, Cargo attendance and transportation (sea freight and air freight) [V], and Logistics (Personal logistics and Logistics base facilities) [L]. The study concluded Consolidated Shipping Agency (Conship) was the best Logistics Service Provider to offer the best consolidated services for project optimization under the TEN project.
\end{abstract}

Key words: Logistics service providers, analytical hierarchy process, subsea engineering, weighted scoring model.

\section{Introduction}

Crude oil and its products are very fundamental commodities which play key role in industrial sustainability. Ghana's first offshore oil was discovered in the 1970's off the coast of Saltpond in the Central Region by Agri-Petco International [1]. In 2004 Ghana sold licenses for offshore oil exploration and production to different international companies [2], and in July 2007, Kosmos Energy announced the discovery of an oil field at the West Cape Three of Ghana to contain up to three billion barrels of light crude oil. Over the past eight years, exploration for commercial hydrocarbons in Ghana has intensified with activities undertaken by Tullow Oil, Kosmos Energy, Hess Corporation, Hunt Oil, Afren and Norsk Hydro Oil and Gas among others. This discovery made Ghana joined the ranks of West African oil producers

Corresponding author: Jonas Aryee, M.Sc., assistant lecturer, research field: Transport Economics. in mid-December 2010 and also helped Ghana to register one of the highest economic growth rates in the world in 2011 [3]. Since 2007 further discoveries have been made. The Tweneboa, Enyenra and Ntomme (TEN) fields are the Ghana's second major discovery located in Deepwater Tano contract area about 60 kilometres off the coast of Ghana [4].

Larger percentage of the world's consumption of petroleum energy has resulted in the advent of many technological and engineering industries that are into building and installation of superstructures for the exploitation and extraction of the petroleum products. Tullow has licensed the following subsea engineering companies: Technip, Subsea 7, Seaweld Engineering Ltd, Mitsui Ocean Development and Engineering C. Ltd (MODEC), Orsam Ltd., Hydra offshore limited, Wood group Limited and Harlequin International Ghana Ltd are among these engineering industries for the building of superstructure for the TEN project. 

Enyenra and Ntomme (TEN) Project in Ghana

These subsea engineering companies consider quality services, health and safety conditions and environmental protection as their topmost priorities [5]. Oil and gas is a timely international industry and Ghana is new to it. As a result of this, the local service providers have not been able to meet up with the quality standards and some do not have health, safety and environment protection policies. Murat and Ozer [6] state, that one of the main risks of contracting a third party is related to the quality of the offered services. Furthermore, the local service providers have not yet understood the demands of the oil and gas industry e.g. timely response to email and timely delivery of goods and services. The delay in the provision of services by local service providers has led to the delay in the execution of Subsea Engineering companies projects. This study seeks to identify and assess local service providers to ascertain whether their capabilities meet the standard in the offshore industry.

\subsection{The Concept of Strategic Third Party Logistics} Service Providers

A strategic local third party logistics service provider is a service provider operating in an immediate vicinity such as a sub region or country and who follows all related rules and regulations in that country and able to timely deliver goods and services. The strategic service provider model is emerging because time utility is important in any business activity. The various methods/models of third party service provider selection and evaluation according to Ref. [8] are: Linear weighting models, Artificial intelligence, Statistical/probabilistic approaches, and Mathematical programming models with the most utilized methods are linear weighting models. The timing is right for a strategic level because subsea

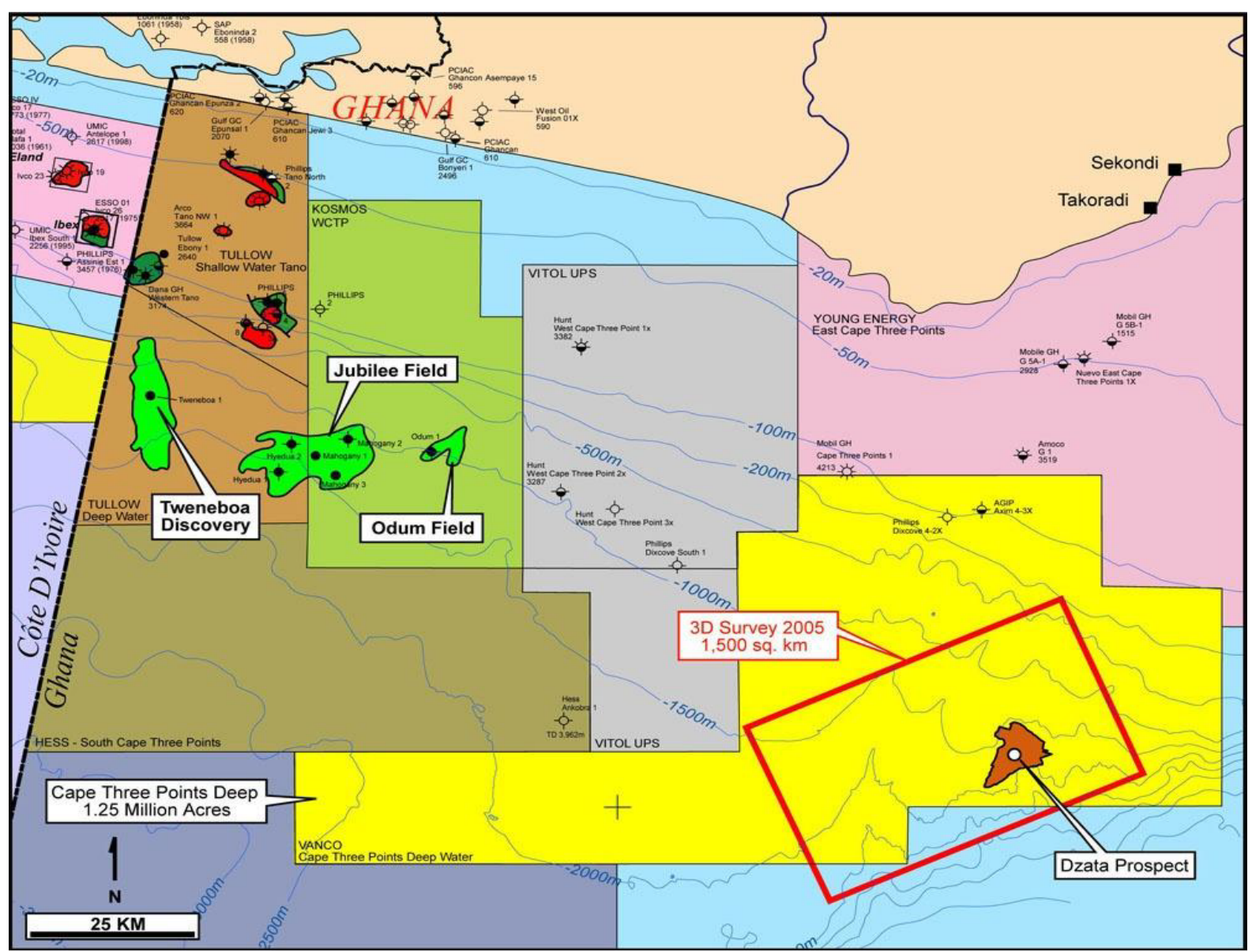

Fig. 1 Ghana's oil findings (source: Ref. [7]). 
engineering companies need strategic service providers to represent them to their customers [9]. According to Ref. [9], the strategic service providers are very powerful and capable of steering customers to the technology and business practices the strategic service providers believe are best for business over the long run.

The concept of third party logistics (3PL) has been developed from the need to extend transportation services by transportation companies to its customers. Laarhoven and Berglund [10], define the outsourcing of logistics activities - called third party logistics - as "activities carried out by a logistics service provider on behalf of a shipper and consisting of at least management and execution of transportation and warehousing". In addition, the authors state that it includes other activities such as inventory management, information related services or supply chain management.

There are several criteria authors used in selecting the strategic service provider. Bagchi and Virum [11] indicated that some of the selection criteria are developed which are common for all circumstances but there are some with specific client needs in mind. For the initial screening of the logistics service providers, according to Ref. [12], supplier reputation, response to information request and references from clients are the qualitative factors that are considered. However, Aghazadeh [13], Sink et al. [12], van Damme and Ploos van Amstel [14] indicated the types of the product, prior experience of the customers experience and regulations as an essential factors in selecting service provider. Papadopoulou [15] on the other hand indicated technology, quality, expertise, leverage, responsiveness, delivery, cost, price, reputation, track record, references, balance sheet, access to capital, resources, corporate culture fit, prospects for partnership, commitment and flexibility, reputation and recommendation, area of service coverage, added value services, order processing, financial and punctuality as the criteria for selection of third party logistics service provider.

\section{Research Methodology}

\subsection{Research Design}

The study used both quantitative and qualitative method in line with positivist and interpretivist theories. Tashakkori and Teddlie [16] stated that both qualitative and quantitative approaches have specific margins and particular strengths. As a result the two approaches should be combined so the two approaches can compensate for their mutual weaknesses. The data obtained from the research were analyzed to gain necessary knowledge from the various situations.

\subsection{Target Population and Sample Size}

Logistics service providers and industry experts from Technip, Subsea 7, Seaweld Engineering Ltd., Orsam Ltd., MODEC, Hydra Offshore Limited, Wood Group Limited and Harlequin International Ghana Ltd. formed the target population of the study. Twenty service providers and 7 subsea engineering companies were identified forming a total population. Out of the twenty service providers, the researchers purposely selected 8 and all the 7 subsea engineering companies were selected to form the sample size.

\subsection{Sampling Procedure}

The sampling procedure used was simple random sampling for selecting the service providers which include Consolidated Shipping Agency (Conship) Ghana Limited, Jonmoore International, Macro Group, Maiden Group of Companies, Oil and Marine Agency (OMA) Ghana Limited, Stellar Logistics, Transglobal Logistics, and UT Logistics.

\subsection{Research Instrument}

The instruments used by the researchers in carrying out the research were:

Observation: Personal observations of the assets and facilities of the logistics service providers were made 

Enyenra and Ntomme (TEN) Project in Ghana

by the researchers in order to affirm the responses from the questionnaires. This enabled the researchers to analyze and attribute scores to the service providers;

Questionnaires: Questionnaires submitted to the relevant experts of all the seven subsea engineering companies in order to assess the selection criteria to be used and rate local service providers according to their preferences.

\section{The WSM (Weighted Scoring Model)}

According to Refs. [17, 18], the WSM plainly identifies decision factors (selection criteria), and each alternative (logistics service provider) is compared to the factors. He further stated that, the decision model addresses many factors. A numerical value is assigned to each alternative for each factor. The various factors are weighted differently. The weighted numerical values are added, and the alternative with the highest score is the best overall alternative. The WSM is a powerful and flexible model that guide in decision making. The model provides a level of objectivity in the matters where subjectivity could have major negative consequences. The model can be used in different areas such as project and product selection, technology, solution design and risk response analysis [19].

\subsection{Weighted Scoring Model Steps:}

Step 1: Define the decision factors (selection criteria).

Step 2: Assign importance levels or weights to each decision factor (selection criteria).

As illustrated by Ref. [20], to determine the weight of the different selection criteria, the following two-step procedure, derived from the AHP (Analytical Hierarchic Process) is used.

Let $\mathrm{m}$ be the number of selection criteria, arbitrarily sorted, and let $\mathrm{A}$ be an $\mathrm{m} \mathrm{x}$ m matrix whose entry $\mathrm{a}_{\mathrm{kj}}, \mathrm{k}$ $=1, \ldots, m, j=1, \ldots, m, k \neq j$, indicates the relative importance of criterion $\mathrm{k}$ with respect to criterion $\mathrm{j}$ and $\mathrm{a}_{\mathrm{jk}}=1 / \mathrm{a}_{\mathrm{k}}, \mathrm{k}=1, \ldots, \mathrm{m}$, should be put in the formula, that is, $\mathrm{k}=1, \ldots, \mathrm{m}, \mathrm{j}=1, \ldots, \mathrm{m}, \mathrm{k} \neq \mathrm{j}$. Entries $\mathrm{a}_{\mathrm{k} k}, \mathrm{k}=$ $1, \ldots, \mathrm{m}$, of the diagonal are equal to 1 .

Let $\mathrm{c}_{1}, \mathrm{c}_{2}, \mathrm{c}_{3}, \ldots \mathrm{c}_{\mathrm{n}}$ be the selection criteria used in selecting the service providers;

Therefore,

\begin{tabular}{|c|c|c|c|c|c|c|}
\hline \multirow[t]{7}{*}{ Matrix A = } & & $\mathrm{c}_{1}$ & $\mathrm{c}_{2}$ & $c_{3}$ & $\ldots$ & $\mathrm{c}_{\mathrm{n}}$ \\
\hline & $\mathrm{c}_{1}$ & $\mathrm{a}_{11}$ & $\mathrm{a}_{12}$ & $\mathrm{a}_{13}$ & $\ldots$ & $a_{1 n}$ \\
\hline & $\mathrm{c}_{2}$ & $\mathrm{a}_{21}$ & $\mathrm{a}_{22}$ & $a_{23}$ & $\ldots$ & $a_{2 n}$ \\
\hline & $\mathrm{c}_{3}$ & $\mathrm{a}_{31}$ & $a_{32}$ & $a_{33}$ & $\cdots$ & $a_{3 n}$ \\
\hline &.. & . & . & $\ldots$ & . & \\
\hline & . & . & . & . & $\ldots$ & . \\
\hline & $\mathrm{c}_{\mathrm{m}}$ & $\mathrm{c}_{\mathrm{m} 1}$ & $\mathrm{c}_{\mathrm{m} 2}$ & $\mathrm{c}_{\mathrm{m} 3}$ & $\ldots$ & $\mathrm{c}_{\mathrm{mn}}$ \\
\hline
\end{tabular}

Standard scale of values associated with a comparison between the selection criteria $\mathrm{k}$ and $\mathrm{j}$ as suggested by Saaty [21] are:

Representing the geometric mean of the elements of the $\mathrm{k}^{\text {th }}$ row of $\mathrm{A}$. The weight of each criterion $\mathrm{k}$ is then determined as;

$$
\mathrm{W}_{\mathrm{k}}=\frac{\ddot{w} k}{\sum_{i=1}^{m} \ddot{w} i}, k=1, \ldots, m
$$

The resulting weights are normalized so that,

$$
\begin{aligned}
& \text { Weight } \mathrm{i}=\frac{\sum_{j=1}^{n} a i j *}{n} \\
& \qquad \sum_{k=1}^{m} W k=1
\end{aligned}
$$

The WSM attributes a total score to each logistics service providers, on the basis of the chosen selection criteria.

Let $\mathrm{V}$ be the set of potential logistics service providers. A weight $\mathrm{W}_{\mathrm{k}} \in(0,1)$ is associated to each selection criterion $\mathrm{k}$ on the basis of its importance with respect to the other criteria.

Step 3: Mapping scale for decision factor into scores

Table 1 Comparison judgment between 2 criteria.

\begin{tabular}{lll}
\hline Comparison judgment between criteria $\mathrm{k}$ and $\mathrm{j}$ & $\mathrm{a}_{\mathrm{kj}}$ & $\mathrm{a}_{\mathrm{j} \mathrm{k}}$ \\
\hline $\mathrm{k}$ and $\mathrm{j}$ are equally important & 1 & 1 \\
$\mathrm{k}$ is moderately preferable to $\mathrm{j}$ & 3 & $1 / 3$ \\
$\mathrm{k}$ is quite preferable to $\mathrm{j}$ & 5 & $1 / 5$ \\
$\mathrm{k}$ is decidedly preferable to $\mathrm{j}$ & 7 & $1 / 7$ \\
$\mathrm{k}$ is extremely preferable to $\mathrm{j}$ & 9 & $1 / 9$ \\
$\mathrm{j}$ is moderately preferable to $\mathrm{k}$ & $1 / 3$ & 3 \\
$\mathrm{j}$ is quite preferable to $\mathrm{k}$ & $1 / 5$ & 5 \\
$\mathrm{j}$ is decidedly preferable to $\mathrm{k}$ & $1 / 7$ & 7 \\
$\mathrm{j}$ is extremely preferable to $\mathrm{k}$ & $1 / 9$ & 9 \\
\hline
\end{tabular}




\section{Enyenra and Ntomme (TEN) Project in Ghana}

Let $S_{i k}, i \in V$, be the score (from 1 to 5 ) associated with selection criterion $\mathrm{k}$ for subcontractor $\mathrm{i}$. The scores attributed to the service providers by the researchers were

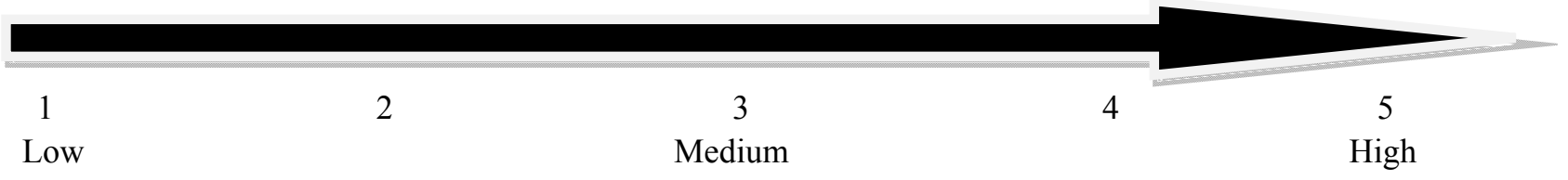

Step 4: Score each decision factor (selection criteria) for each alternative, multiply the score by its weights and sum the weighted scores.

The total score $r_{i}$ of the service providers $i \in V$ is calculated as,

$$
\mathrm{r}_{\mathrm{i}}=\sum_{k=1}^{m} W k S i k
$$

Since a service provider ( $\left.i^{*}\right)$ has to be selected, the one with the highest total score is chosen, that is, $i^{*}=$ $\operatorname{argmax}\left\{\mathrm{r}_{\mathrm{i}}\right\}$.

\section{Data Analysis and Presentation of Results}

\subsection{Activities Outsourced by the Subsea Engineering} Companies

The subsea engineering companies normally outsource their logistics task in order to meet project scheduled deadlines since logistics is not their core activity. The following logistics activities are outsourced: Shipping and Vessel attendance, Freight forwarding and cargo attendance and Husbandry services/Personnel attendance.

The selection criteria used in selecting the service providers is based on local content requirement and the capacity of the Logistics service providers to handle the full scope (shipping and vessel attendance, freight forwarding, cargo attendance, husbandry service and personnel attendance).

\subsection{Selecting a Service Provider for Optimization}

This section deals with selecting a local service provider that can provide a one-stop-shop service to subsea engineering companies. This will enable Subsea engineering Company to easily monitor the efficiency and effectiveness of the service provider. Furthermore, a one-stop-shop service provider will enable Subsea engineering Company minimize its cost of operation, and ensure there is adequate provision of materials and services on time and also, it will simplify the integration of the logistics processes between Subsea engineering Company and the selected service provider.

\subsection{Analysis of Service Providers Using the Weighted Scoring Model}

Step 1: Define the selection criteria

The selection criteria used are:

Quality, Health, Safety and Environmental (QHSE) policies [Q];

Compliance to regulations (GRA, Work permit, petroleum regulation) $[\mathrm{C}]$;

Delivery of goods on time and response rate to deliver [D];

Vessel, Cargo attendance and transportation (sea freight and air freight) [V];

Logistics (Personal logistics and Logistics base facilities) [L].

Step 2: Assign importance levels or weights to each selection criteria using standard scale developed by Saaty [21]

(1) Pair wise comparison matrices $\mathrm{A}=$

- $\mathrm{A}_{\mathrm{QQ}}=1$, it implies that QHSE policies and QHSE policies are equally important as stated by Saaty;

- $\mathrm{A}_{\mathrm{QC}}=5$, it implies that QHSE policies is quite preferable to Compliance to regulations as compared

$\left.\begin{array}{|l|}\hline \text { Q } \\ \hline \text { C } \\ \hline \text { D } \\ \hline \text { V } \\ \hline \text { L }\end{array}\right]\left[\begin{array}{c|c|c|c|c|}\hline \\ \hline 1 & 5 & 1 & 1 & 1 \\ \hline 1 / 5 & 1 & 7 & 7 & 7 \\ \hline 1 & 1 / 7 & 1 & 9 & 9 \\ 1 & 1 / 7 & 1 / 9 & 1 & 1 \\ 1 & 1 / 7 & 1 / 9 & 1 & 1\end{array}\right]$

Fig. 2 Pair wise comparison matrix A. 
by Subsea engineering companies;

- $\mathrm{A}_{\mathrm{QD}}=1$, it implies that $\mathrm{QHSE}$ policies is equally important to Delivery of goods on time as compared by Subsea engineering companies;

- $\mathrm{A}_{\mathrm{QV}}=1$, it implies that QHSE policies is equally important to Vessel and cargo attendance as compared by Subsea engineering companies;

- $\mathrm{A}_{\mathrm{QL}}=1$, it implies that QHSE policies is equally important to Logistics as compared by Subsea engineering companies;

- $\mathrm{A}_{\mathrm{CQ}}=1 / 5$, it is the reciprocal of $\mathrm{A}_{\mathrm{QC}}$, as stated by Saaty;

- $\mathrm{A}_{\mathrm{CC}}=1$, it implies Compliance to regulation and Compliance to regulation are equally important as stated by Saaty;

- $\mathrm{A}_{\mathrm{CD}}=7$, it implies Compliance to regulation is decidedly preferable to Delivery of goods on time as compared by Subsea engineering companies;

- $\mathrm{A}_{\mathrm{CV}}=7$, it implies Compliance to regulation is decidedly preferable to Vessel and Cargo attendance as stated by Subsea engineering companies;

- $\mathrm{A}_{\mathrm{CL}}=7$, it implies Compliance to regulation is decidedly preferable to Logistics as compared by Subsea engineering companies;

- $\mathrm{A}_{\mathrm{DQ}}=1$, it is the reciprocal of $\mathrm{A}_{\mathrm{QD}}$, as stated by Saaty;

- $A_{D C}=1 / 7$, it is the reciprocal of $A_{C D}$, as stated by Saaty;

- $\mathrm{A}_{\mathrm{DD}}=1$, it implies Delivery of goods on time is equally important to Delivery of goods on time as stated by Saaty;

- $A_{D V}=9$, it implies Delivery of goods on time is extremely preferable to Vessel and Cargo attendance as compared by Subsea engineering companies;

- $\mathrm{A}_{\mathrm{DL}}=9$, it implies Delivery of goods on time is extremely preferable to Logistics as compared by Subsea engineering companies;

- $\mathrm{A}_{\mathrm{VQ}}=1$, it is the reciprocal of $\mathrm{A}_{\mathrm{QV}}$, as stated by Saaty;

- $A_{V C}=1 / 7$, it is the reciprocal of $A_{C V}$, as stated by Saaty;

- $A_{V D}=1 / 9$, it is the reciprocal of $A_{D V}$, as stated by Saaty;

- $\mathrm{A}_{\mathrm{VV}}=1$, it implies Vessel and cargo attendance is equally important to Vessel and cargo attendance as stated by Saaty;

- $\mathrm{A}_{\mathrm{VL}}=1$, it implies Vessel and cargo attendance is equally important to Logistics as compared by Subsea engineering companies;

- $\mathrm{A}_{\mathrm{LQ}}=1$, it is the reciprocal of $\mathrm{A}_{\mathrm{QL}}$, as stated by Saaty;

- $\mathrm{A}_{\mathrm{LC}}=1 / 7$, it is the reciprocal of $\mathrm{A}_{\mathrm{CL}}$, as stated by Saaty;

- $A_{L D}=1 / 9$, it is the reciprocal of $A_{D L}$, as stated by Saaty;

- $\mathrm{A}_{\mathrm{LV}}=1$, it is the reciprocal of $\mathrm{A}_{\mathrm{VL}}$, as stated by Saaty;

- $\mathrm{A}_{\mathrm{LL}}=1$, it implies Logistics is equally important to logistics, as stated by Saaty.

(2) Normalize pair wise matrix A to get $A^{*}$

Each entry in the column is divided by the sum of the entries in that column as shown below. This gives a new matrix by name $A^{*}$ (A normalized)

$$
\mathrm{A}^{*}=\frac{\ddot{w} k}{\sum_{i=1}^{m} \ddot{m} i}, k=1, \ldots, m
$$

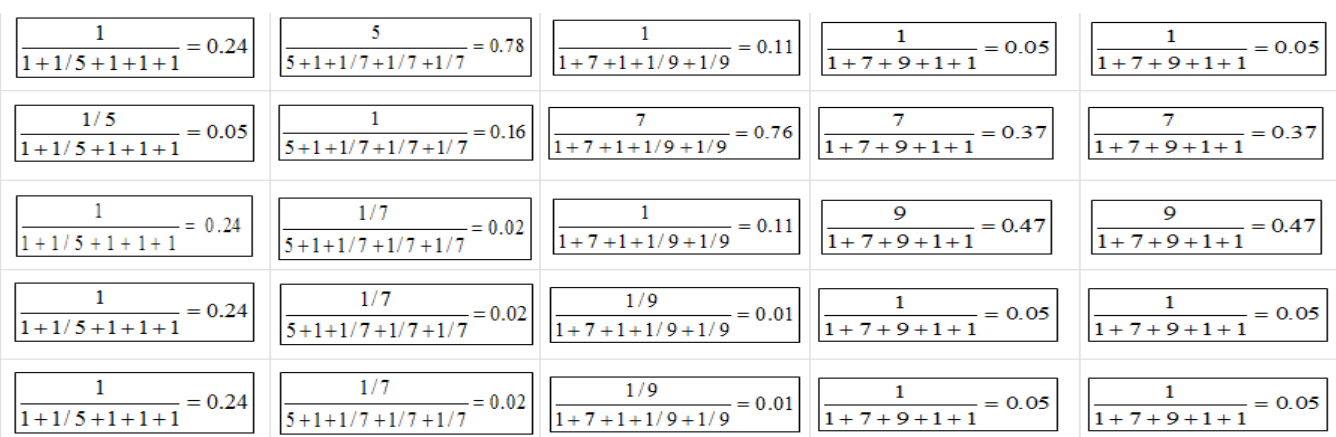


Selecting a Strategic Logistics Service Provider for Subsea Engineering Companies on the Tweneboa, 101 Enyenra and Ntomme (TEN) Project in Ghana

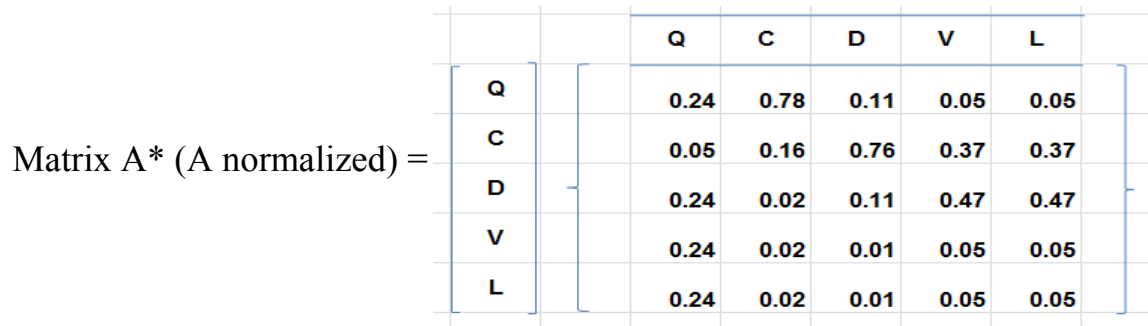

(3) Determine the weight for objective i, as the average of the entries in row i of $\mathrm{A}^{*}$

Weight $\mathrm{i}=\frac{\sum_{j=1}^{n} a i j *}{n}$

$$
\begin{array}{|l|}
\hline \frac{0.24+0.78+0.11+0.05+0.05}{5}=0.25 \\
\frac{0.05+0.16+0.76+0.37+0.37}{5}=0.34 \\
\frac{0.24+0.02+0.11+0.47+0.47}{5}=0.26 \\
\frac{0.24+0.02+0.01+0.05+0.05}{5}=0.07 \\
\frac{0.24+0.02+0.01+0.05+0.05}{5}=0.07 \\
\hline
\end{array}
$$

As suggested by Saaty, $\sum_{k=1}^{m} W k=1$.

Which implies $=0.25+0.34+0.26+0.07+0.07=0.99 \approx 1$.

Therefore, the weight of: $\mathrm{Q}=0.25, \mathrm{C}=0.34, \mathrm{D}=0.26, \mathrm{~V}=0.07$ and $\mathrm{L}=0.07$.

Step 3: Mapping scale for decision factor into scores

(4) Let $\mathrm{S}_{\mathrm{ik}}, \mathrm{i} \in \mathrm{V}$, be the score (from 0 to 5 ) associated with selection criterion $\mathrm{k}$ for subcontractor $\mathrm{i}$. The scores attributed to the service providers by the researchers were

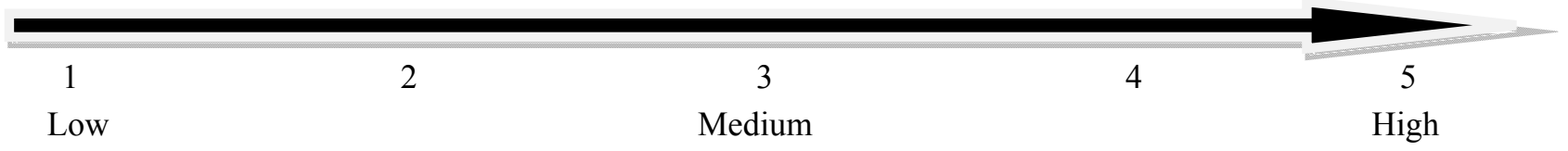

Table 2 Scores for Quality, Health, Safety and Environmental policies.

\begin{tabular}{|l|c|c|c|c|r|r|}
\cline { 2 - 7 } \multicolumn{1}{c|}{} & \multicolumn{7}{c|}{ Scores } \\
\hline \multicolumn{1}{c|}{ Companies } & 1 & 2 & 3 & 4 & Total & Average \\
\hline Conship Ghana & 2.75 & 3.60 & 3.50 & 4.00 & 13.85 & 3.46 \\
\hline Jonmoore International & 1.00 & 3.00 & 2.50 & 3.67 & 10.17 & 2.54 \\
\hline Macro Logisics & 3.00 & 3.30 & 2.25 & 3.67 & 12.22 & 3.06 \\
\hline Maiden Group & 1.50 & 2.30 & 1.75 & 3.67 & 9.22 & 2.31 \\
\hline OMA Ghana & 3.50 & 3.67 & 2.50 & 4.33 & 14.00 & 3.50 \\
\hline Stellar Logistics & 5.00 & 3.60 & 2.50 & 4.00 & 15.10 & 3.78 \\
\hline Transglobal Logistics & 2.50 & 2.00 & 1.00 & 2.33 & 7.83 & 1.96 \\
\hline UT Logistics & 4.25 & 3.00 & 2.25 & 3.33 & 12.83 & 3.21 \\
\hline
\end{tabular}



Enyenra and Ntomme (TEN) Project in Ghana

Table 3 Scores for Compliance to regulation (GRA, Work permit and agency clearance).

\begin{tabular}{|l|c|c|c|c|r|r|}
\cline { 2 - 7 } \multicolumn{1}{c|}{} & \multicolumn{7}{c|}{ Scores } \\
\hline \multicolumn{1}{c|}{ Companies } & 1 & 2 & 3 & 4 & Total & Average \\
\hline Conship Ghana & 4.83 & 4.60 & 3.85 & 4.60 & 17.88 & 4.47 \\
\hline Jonmoore International & 4.30 & 4.20 & 2.66 & 4.20 & 15.36 & 3.84 \\
\hline Macro Logisics & 4.67 & 4.40 & 2.50 & 4.40 & 15.97 & 3.99 \\
\hline Maiden Group & 4.30 & 3.60 & 2.33 & 3.80 & 14.03 & 3.51 \\
\hline OMA Ghana & 5.00 & 3.40 & 3.16 & 3.60 & 15.16 & 3.79 \\
\hline Stellar Logistics & 4.17 & 4.20 & 2.80 & 4.00 & 15.17 & 3.79 \\
\hline Transglobal Logistics & 2.83 & 3.20 & 2.66 & 3.20 & 11.89 & 2.97 \\
\hline UT Logistics & 4.33 & 3.80 & 2.33 & 3.60 & 14.06 & 3.52 \\
\hline
\end{tabular}

Table 4 Scores for Delivery of goods on time.

\begin{tabular}{|l|c|c|c|c|c|c|}
\cline { 2 - 8 } \multicolumn{1}{c|}{} & \multicolumn{7}{c|}{ Scores } \\
\hline Companies & 1 & 2 & 3 & 4 & Total & Average \\
\hline Conship Ghana & 4.25 & 4.00 & 3.25 & 4.67 & 16.17 & 4.04 \\
\hline Jonmoore International & 4.50 & 3.00 & 2.75 & 4.67 & 14.92 & 3.73 \\
\hline Macro Logisics & 4.75 & 3.60 & 2.33 & 4.00 & 14.68 & 3.67 \\
\hline Maiden Group & 3.00 & 2.60 & 1.75 & 3.00 & 10.35 & 2.59 \\
\hline OMA Ghana & 3.50 & 3.60 & 3.25 & 4.00 & 14.35 & 3.59 \\
\hline Stellar Logistics & 4.25 & 3.60 & 2.75 & 4.30 & 14.90 & 3.73 \\
\hline Transglobal Logistics & 3.50 & 2.30 & 2.00 & 3.00 & 10.80 & 2.70 \\
\hline UT Logistics & 3.75 & 4.00 & 2.75 & 4.33 & 14.83 & 3.71 \\
\hline
\end{tabular}

Table 5 Scores for Vessel, cargo attendance and transportation (sea freight and air freight).

\begin{tabular}{|l|c|c|c|c|r|r|}
\cline { 2 - 7 } \multicolumn{1}{c|}{} & \multicolumn{6}{c|}{ Scores } \\
\hline \multicolumn{1}{c|}{ Companies } & 1 & 2 & 3 & 4 & Total & Average \\
\hline Conship Ghana & 4.33 & 4.50 & 4.00 & 5.00 & 17.83 & 4.46 \\
\hline Jonmoore International & 5.00 & 4.00 & 1.67 & 4.50 & 15.17 & 3.79 \\
\hline Macro Logisics & 4.65 & 4.50 & 2.66 & 4.00 & 15.81 & 3.95 \\
\hline Maiden Group & 2.00 & 4.50 & 2.66 & 4.00 & 13.16 & 3.29 \\
\hline OMA Ghana & 3.00 & 4.00 & 3.00 & 4.00 & 14.00 & 3.50 \\
\hline Stellar Logistics & 5.00 & 3.00 & 3.00 & 3.50 & 14.50 & 3.63 \\
\hline Transglobal Logistics & 2.00 & 2.00 & 2.66 & 3.00 & 9.66 & 2.42 \\
\hline UT Logistics & 4.30 & 3.00 & 1.66 & 4.33 & 13.29 & 3.32 \\
\hline
\end{tabular}

Table 6 Scores for Logistics (Personal logistics and logistics base facilities).

\begin{tabular}{|l|c|c|c|c|r|r|}
\cline { 2 - 7 } \multicolumn{1}{c|}{} & \multicolumn{7}{c|}{ Scores } \\
\hline \multicolumn{1}{|c|}{ Companies } & 1 & 2 & 3 & 4 & Total & Average \\
\hline Conship Ghana & 4.00 & 4.00 & 3.30 & 4.50 & 15.80 & 3.95 \\
\hline Jonmoore International & 5.00 & 4.50 & 3.30 & 4.50 & 17.30 & 4.33 \\
\hline Macro Logisics & 3.65 & 2.50 & 2.00 & 2.50 & 10.65 & 2.66 \\
\hline Maiden Group & 2.30 & 3.50 & 2.66 & 4.00 & 12.46 & 3.12 \\
\hline OMA Ghana & 2.67 & 4.50 & 2.33 & 3.00 & 12.50 & 3.13 \\
\hline Stellar Logistics & 4.67 & 4.00 & 2.66 & 4.00 & 15.33 & 3.83 \\
\hline Transglobal Logistics & 2.33 & 2.50 & 2.00 & 3.00 & 9.83 & 2.46 \\
\hline UT Logistics & 4.30 & 4.00 & 3.00 & 4.50 & 15.80 & 3.95 \\
\hline
\end{tabular}

Step 4: Score each decision factor (selection criteria) for each alternative, multiply the score by its weights and sum the weighted scores.

- The total score $r_{i}$ of the service providers ic $\mathrm{V}$ is calculated as,

- The weight of each selection criteria is multiplied by the average of the scores.

$\mathrm{r}_{\mathrm{i}}=\sum_{k=1}^{m} W k S i k$

Calculation of total weighted score 


\section{Enyenra and Ntomme (TEN) Project in Ghana}

\begin{tabular}{|l|l|l|}
\hline Conship & $=0.25(3.46)+0.34(4.47)+0.26(4.04)+0.07(4.46)+0.07(3.95)=4.02$ \\
\hline Jonmoore International & $=0.25(2.54)+0.34(3.84)+0.26(3.73)+0.07(3.79)+0.07(4.33)=3.48$ \\
\hline Macro Group & $=0.25(3.06)+0.34(3.99)+0.26(3.67)+0.07(3.95)+0.07(2.66)=3.54$ \\
\hline Maiden Group & $=0.25(2.31)+0.34(3.51)+0.26(2.59)+0.07(3.29)+0.07(3.12)=2.89$ \\
\hline OMA Ghana & $=0.25(3.50)+0.34(3.79)+0.26(3.59)+0.07(3.50)+0.07(3.13)=3.56$ \\
\hline Stellar Logistics & $=0.25(3.78)+0.34(3.79)+0.26(3.73)+0.07(3.63)+0.07(3.83)=3.73$ \\
\hline Transglobal Logistics & $=0.25(1.96)+0.34(2.97)+0.26(2.70)+0.07(2.42)+0.07(2.46)=2.54$ \\
\hline UT Logistics & $=0.25(3.21)+0.34(3.52)+0.26(3.71)+0.07(3.32)+0.07(3.95)=3.47$
\end{tabular}

Table 7 Total weighted score of service providers.

\begin{tabular}{|c|l|c|}
\hline Number & Companies & Ranking \\
\hline 1 & Conship & 4.02 \\
\hline 2 & Stellar & 3.73 \\
\hline 3 & OMA & 3.56 \\
\hline 4 & Macro & 3.54 \\
\hline 5 & Jonmoore & 3.48 \\
\hline 6 & UT Logistics & 3.47 \\
\hline 7 & Maiden & 2.89 \\
\hline 8 & Transglobal & 2.54 \\
\hline
\end{tabular}

Since a local service provider $\left(i^{*}\right)$ has to be selected, the one with the highest total score is chosen, that is, $\mathrm{i}^{*}$ $=\operatorname{argmax}\left\{\mathrm{r}_{\mathrm{i}}\right\}$.

\subsection{Discussion of the Results}

From that analysis of the variables considered, Conship had the score of 0.25 in vessel attendance, and 0.15 in the areas of cargo attendance and timely delivery of goods as compared to other service providers. In the areas of personal logistics, the Conship, Stellar Logistics and Maiden Group have the highest scores of 0.18 each. However, when it comes the area of logistics base facilities, Jonmoore International had the highest score of 0.21 as compared to other service providers. Conship attained the highest total weighted score of 4.02 (Table 7), followed by Stellar Logistics with a score of 3.73. OMA, Macro group, Jonmoore International, UT logistics and
Maiden Group attained scores of 3.56, 3.54, 3.48, 3.47 and 2.89 respectively. Transglobal logistics has the lowest score with 2.54 from the weighted scoring model. Hence, from the analysis, Conship can provide the best consolidated service for the SECs.

\section{Conclusion}

The efficacy of service providers much depends on compliance to regulations, availability of assets and how they are effectively used to offer quality service. Throughout this study, the service providers with assets and license prove to have a lot of internal strength to obtain opportunities. In response to the objectives of the study, 8 companies were analyzed and all the companies were local service providers registered in Ghana and operating based on the rules and regulations put in place by the authorities in Ghana. Hence, they all fulfilled the local content requirement, which is part of the selection criteria used by subsea engineering companies in identifying and selecting service providers. It can be concluded that most of the service providers met subsea engineering companies' outsourcing requirements.

\section{References}

[1] Panford, K. 2014. "Oil and Gas Activities in Ghana, Graphic Online.” Accessed May 20, 2015. 
http:/graphic.com.gh/features/opinion/15090-oil-and-gas -activities-in-ghana.

[2] Kastning, T. 2011. Basic Overview of Ghana's Emerging Oil Industry. Accra: FES Ghana.

[3] KPMG Africa Limited. 2013. Africa's Reserves, Potential and Prospects. Swiss: KPMG International.

[4] News Ghana. 2013. "Hydra Offshore Ltd. and Wood Group Ghana Ltd Cement Long Term Relationship for Subsea Engineering Services in Ghana.” Accessed May 20, 2015. http://www.newsghana.com.gh.

[5] Technip. 2013. Technip in Ghana. Published by Technip.

[6] Murat, K., and Ozer, O. 2009. "Quality Risk in Outsourcing: Noncontractible Product Quality and Private Quality Cost Information.” Published online 27 July 2009 in Wiley Inter Science. http://www.interscience.wiley.com.

[7] Ashiadey, B. Y. 2013. "Ivory Coast's Oil Find Won't Impact Ghana's-Tullow, Business and Financial Times." Accessed April 3, 2015. http://ghanaoilonline.org.

[8] Aicha, A. 2007. "The Third Party Logistics Selection: A Review of Literature." International Logistics and Supply Chain Congress, Istanbul, Turkey, 7.

[9] Faletra, R. 2014. "The Birth of the Strategic Service Provider." Accessed March 17, 2015. http://www.crn.com/blogs-op-ed/cloud/300075098/the-bi rth-of-the-strategic-service-provider.htm.

[10] Laarhoven, P., and Berglund, M. A. 2000. "Third Party Logistics, Is There A Future?" International Journal of Logistics Management 10 (1): 59-70.

[11] Bagchi, P. K., and Virum, H. 1996. "European Logistics Alliances: A Management Model." International Journal of Logistics Management 7 (1): 93-108.

[12] Sink, H. L., and Langley, C. J. 1997. “A Managerial Framework for the Acquisition of Third-Party Logistics Services." Journal of Business Logistics 18 (2): 163-89.

[13] Aghazadeh, S. M. 2003. "How to Choose an Effective Third Party Logistics Provider." Management Research News 26 (7): 50-8.

[14] van Damme, D. A., and Ploos van Amstel, M. J. 1996 "Outsourcing Logistics Management Activities." International Journal of Logistics Management 7 (2): 85-95.

[15] Papadopoulou, C. (n.d). "An Overview of Third Party Logistics Industry." Centre for Transportation Studies, Massachusetts Institute of Technology.

[16] Tashakkori, A., and Teddlie, C. 2003. Handbook of Mixed Methods in Social and Behavioral Research. Thousand Oaks: Sage.

[17] Celeste, N. (n.d.). "Economics in IS/IT Decision-Making, Lecture Note." Accessed March Thursday, 2015. http://www.mis.yzu.edu.tw.

[18] ABS Consulting. 2012. Principles of Risk-Based Decision Making, Kindle edition. Published by Government Institute.

[19] Zimmer, D. A. 2011. "What is the Weighted Scoring Method." Accessed May 25, 2015. http://terms.ameagle.com/2011/01/david.html.

[20] Gianpaolo, G., Gilbert, L., and Roberto, M. 2013. Introduction to Logistics System Management, 2nd ed.

[21] Saaty, T. 1980. The Analytic Hierarchy Process. New York: McGraw-Hill. 